\title{
A Plea for the Small Orchestra
}

Author(s): G. Jean-Aubry

Source: The Musical Times, Vol. 59, No. 907 (Sep. 1, 1918), pp. 421-422

Published by: Musical Times Publications Ltd.

Stable URL: http://www.jstor.org/stable/909660

Accessed: 18-04-2016 11:49 UTC

Your use of the JSTOR archive indicates your acceptance of the Terms \& Conditions of Use, available at

http://about.jstor.org/terms

JSTOR is a not-for-profit service that helps scholars, researchers, and students discover, use, and build upon a wide range of content in a trusted digital archive. We use information technology and tools to increase productivity and facilitate new forms of scholarship. For more information about JSTOR, please contact support@jstor.org.

Musical Times Publications Ltd. is collaborating with JSTOR to digitize, preserve and extend access to The Musical Times 
The following extract from a letter addressed to $M$. Jean de Reszke, his father, by one of the comrades of this brilliant officer, indicates in what heroic manner Lieutenant de Reszke died:

A counter-attack had been ordered with the object of retaking the village of Méry. Dear Jean started thither with joy; he was happy to do his duty with a disinterestedness of which he only was capable, the danger appearing to attract him. $\mathrm{He}$ was sent to reconnoitre the outskirts of the village, and when he had completed his survey returned to fetch his men. He had Leverdier not far from him and he led his troops with an absolute calm. He arrived at the borders of the village almost without loss. But when he arrived at the houses, the resistance was serious. Jean perceived that the Germans threatened to come between him and the troops of Leverdier; he approached the latter in order to make the necessary dispositions so that they should not be cut off from each other, and went to render an account to the commandant of the company of what was taking place. The Captain sent Jean with his section to stop this progression of the enemy. He placed his men in small groups and advanced bravely. . . . . It was at this moment he received a shot in the head. .... He fell, having attained his objective with his section which he loved so much and by whom he was adored. There was no time before the fatal moment to pin on his breast the croix de la Légion d'Honneur. Jean had been recommended for mention by the Army ; he it was who ensured the success of this operation at Méry.

We offer our deepest sympathy to Dr. Gray and to M. Jean de Reszke.

\section{Reviews.}

Three in One, and One in Three. Words by G. Rorison, music by F. W. Wadely. (Novello's Chorister Series, No. 6r.)

Let us now fear the Lord our God. Anthem for Harvest. By Arthur M. Goodhart. (Novello's Octavo Anthems, No. 1066.)

[Novello \& Co., Ltd.]

Mr. Wadely's setting of the well-known hymn is for treble chorus, chiefly in unison, two-part writing being reserved for the last page. It is one of the best works of its kind we have met with, being well written for both voice and organ, and very expressive.

Mr. Goodhart's anthem is bold and straightforward in style. It is easy to sing, and should meet the case of depleted choirs at coming Harvest Festivals, for which its iubilant final portion is well suited.

Church Music: A plea for a simple service in Village, Town, and Cathedral. By C. Lee Williams and A. Herbert Brewer.

[Chance \& Bland, Gloucester.]

This is a reprint of two lectures delivered a few years ago. The fact is worth noting, because Mr. Lee Williams's suggestive paper anticipates in several respects the recently published Report of the Archbishops' Committee. Both lectures take a practical and commonsense view of the subject, asking for a sense of proportion and fitness in the use of elaborate music, and for a more definite recognition of the part of the congregation.

Dr. Brewer's lecture contains many valuable practical hints on technical points in choir work, and concludes with a brief historical survey of Church music. The pamphlet deserves the attention of clergy and organists.

In a contribution headed 'Japan as a Sanctuary for Russians,' that appeared in The Times on August 7, the writer gives an account of the peaceful invasion of Japan by Russians fleeing from the Bolshevik Government. He says 'A happy side of this Russian invasion has been the number of pianists, violinists, singers, and dancers, a motley train, who have entertained the Japanese public well. It is safe to predict that this contact of Russian art upon the impressionable Japanese will have some permanent result.'

\section{A PLEA FOR THE SMALL ORCHESTRA.}

\author{
By G. JEAN-AUBRY.
}

Amongst the many objectionable ideas which Germany with so much tenacity and narrowness of mind has endeavoured to spread abroad, is the conception of the orchestra as an organization multipliable $a d$ infinitum, quantity being made at least as important as quality.

The German primitive regard for the 'Kolossal' shows itself in this sphere as in so many others. In the orchestra instruments have been doubled to such an extent that each is nothing but a soulless mechanical contrivance and obedient machine in the hands of the conductor. Richard Strauss, and more especially Gustav Mahler, are two of the greatest sinners. It is high time that we came back to saner ideas, and returned to traditions of moderation and proportion from which the German mind has departed.

It is intolerable that in order to employ our modern orchestras to the full, the parts in the Symphonies of Haydn and Mozart have been multiplied in an arbitrary manner. Thus we succeed in giving only a false impression of values, and disadvantageously change their colour without adding compensation. I had the privilege, shortly before the War, of hearing one of Haydn's Symphonies given with the same number of instruments as were used at its first performance under Haydn's direction at Count Esterhazy's. I was agreeably surprised to find how the charm, the colour, the imperceptible gradations in each one of the movements of this Symphony struck me. They seemed to stand out more clearly, effectively, subtly, than I had deemed possible. The same impression was conveyed to me on hearing a more modern work, Wagner's 'Siegfried Idyll,' performed by an orchestra of the size for which it was written. Had I not already been convinced of the effectiveness of the small orchestra from the point of view of sound, these two experiences would have sufficed to convert me. But now other considerations persuade me of the necessity for advocating the advantages of the small orchestra, and the part it can play in musical life and creation.

The reasons favouring the cause of the small orchestra are manifold. First of all, from a practical point of view, it is a truism that it is easier to find thirty instrumentalists than eighty or a hundred. In the same way it is easier to unite thirty good instrumentalists than eighty or a hundred. It is a truism also that the first business of an orchestra is to be composed of good players, for this condition is essential to a satisfactory performance. A second condition is that these good players should take the trouble to practise the works which they are to perform ; to ensure this, a good conductor is necessary and as great a number of rehearsals as possible. Thus, in the same manner, it is easier to assemble frequently thirty good players than eighty or a hundred. It is also easier to find the means to pay for the time that is necessary for rehearsal with this number of players than in the case of eighty or a hundred, and accommodation for rehearsal is easier to obtain.

Greater facility in bringing together good performers, more frequent rehearsals, smaller expenses-these are all arguments in favour of the small orchestra, but there are still others. One is unfortunately the result of present-day circumstances. We cannot hide the fact that our orchestras, like all other human organizations, will find themselves decimated by the losses they have sustained during the War. No doubt in this sphere women will come forward-they have done so already - to take the place of musicians who have fallen on the field of honour. But this substitution, relatively easy in certain large towns, becomes much more difficult in towns where performers are scarce.

Such reasons might induce some persons to regard the small orchestra as a makeshift ; but against this we must put forward reasons of an æsthetic and spiritual order.

First it is hard to understand why music should be deprived of means of expression within its reach, and why the heare should necessarily have to take his choice between the big orchestra and chamber music. Why not the chamber orchestra? Why should we have a right to hear the trio, the quartet, the quintet, the sextet, very rarely the septet, and from that figure onwards necessarily arm ourselves with four horns, two harps, a tuba, and other instruments? Why should there be no middle course between the small dinner party and the great banquet? The progressive 
improvement, the complexity of the instruments used in the orchestra of to-day, afford endless variety in the combination of tone; but why should this seeking after colour and expressive sound be confined to works for the large orchestra?

Musical culture and taste, and interest in instrumental music, have grown considerably in occidental countries during the last century. This is an additional reason for following a course by means of which our ear would become more acute and sensitive. Would it not be interesting and profitable to put hearers into more intimate touch with the tone-values, the possibilities of the various instruments? I question whether more than a small minority of the frequenters of orchestral concerts are capable of recognizing the tones of the various wind instruments or of defining the part they play in the orchestra.

The following seem to me some of the special functions of the small orchestra, or, as we may call it, the "chamber orchestra': To let each of the instruments play a more definite, a more individual part in the whole scheme, and contribute rare and as it were personal qualities, thus establishing a greater intimacy between the audience and the players; to incite the auditor directly to study the expressive resource of this or that instrument, the player on the other hand finding himself no longer called upon to take the part of a supernumerary, but, according to circumstances, a principal or a secondary one. And here it is for the wise composer writing for the small orchestra not to bring all the 'dramatis persone' of his troop into the foreground at once, but to arrange the parts so as exactly to fit into the proportions of the ensemble. There are infinite possibilities in a combination formed by a double quartet, a harp, and a few wind instruments, for example, and nine or ten to thirty or thirty-five instruments can be mingled in such a manner that all of us might acquire a more intimate knowledge of their colouring properties, if I may thus express it.

At the same time, having smaller means at their disposal as regards quantity, composers would strive to follow more closely the old maxim which after all remains the most important one in a work of art: "the greatest possible effect with the smallest possible means.' They would take more pains to use each instrument characteristically, and thus subterfuge would become unnecessary. Each instrument would play an important part in the whole, and we should be spared any juggling with instruments through insufficient knowledge of their peculiarities. Every detail of the chamber orchestra would become as clearly defined as in a string quartet.

Here is an endless field for the ingenuity of composers, a satisfaction for the mind, an opening of new vistas for audiences, of constant and absorbing interest.

Greater care in organization, smaller expenses, increase in importance of each instrument, stricter individualisation in the part played by each instrumental personality, a bringing of the audience into closer touch with the different elements of the orchestra and accustoming them to new combinations of timbre, a greater facility for the composer to get his work performed, all these features are united in the idea of the chamber orchestra.

Let no one say that a small orchestral society would find no works to perform. It would have the Concertos of Bach, the Symphonies of Haydn, of Mozart, most of the works of Händel, the greater part of the concertos, cantatas, operas, and oratorios (in which latter it has been the custom to increase absurdly the number of performers, as in the case of the 18th-century symphonies, from sheer worship of the colossal and gigantic). Thus most of the music of the $16 \mathrm{th}$, I 7 th, and I 8 th centuries would be available for such a Society. This is a vast enough programme to suffice for any series of concerts. But there is also modern foreign music, Russian or French.

This tendency to fight against the Teuton cult of the colossal orchestra has not been born of the War. In France a number of composers have long been imbued with this idea. Without going back to works like the 'Blessed Damozel,' by Claude Debussy, or to the orchestration of 'Pélleas and Mélisande,' which is a model of moderation ; without teing confined to works included in chamber music, like Charles Bordes's 'Suite Basque' or Ravel's Introduction et Allegro, or Florent Schmitt's Andante et Scherzo, there were before the War other works written for the small orchestra, e.o., Ravel's 'Ma Mère l'Oye,' or Albert Roussel's 'Festin de l'Araignée,' or Gabriel Fauré's 'Dolly,' which were so well appreciated at the Théatre des Arts in Paris during I 1912 and 1913.

The objection could be raised that these works were the accompaniments of ballets, but their musical qualities were such that they soon were given at orchestral concerts, often, alas! with augmented resources, because in France there are no small orchestral societies whose aim is to interpret these works according to their composers' intentions.

Let the Germans if they have a mind to do so continue to pile up instrument upon instrument, write symphonies with eight or twelve horns and three or four tubas, give a free course to their monomania for the gigantic, while we, following the precepts of Purcell and Rameau, and especially of Mozart the unsurpassable, endeavour to multiply those rarer ensembles wherein perfection, moderation, and taste are ruling factors, and which are so easily managed and so intimate in character.

\section{A VIOLINIST'S ADVENTURES IN PETROGRAD AND A GERMAN CAMP.}

Owing to the famine and danger now prevailing in Russia, I have been obliged to give up my good violin teaching connection in Petrograd and return to England, where I arrived about two months ago.

In spite of the ever-increasing bad conditions, many good concerts took place in Petrograd last summer, and also in the winter up to March of this year when I left. At a summer resort in the outskirts of Petrograd, a series of orchestral concerts, lasting from May till August, 1917, were given.

Besides being soloist at several of these Symphony Concerts, I played in the Ist violins. The principal conductors were Glazounov, Tscherepnine, and Malko, and on one or two occasions two very young composers, Miklasheoski and Pingout, conducted their own compositions. Once when Tscherepnine required a solo part on the pianoforte in one of his orchestral works he asked me to perform it, which I did to his entire approval. The violinist Kochanski and Press the 'cellist were amongst the soloists at many of the concerts.

Later in the autumn, a series of eight Symphony Concerts was arranged by Koussevitsky. Then there were about twelve concerts devoted entirely to Bach's compositions; works for organ, pianoforte, violin, vocal and choral were given. An item in these programmes that stands out in my memory was the beautiful Concerto for two Violas (accompanied by small orchestra) which is so seldom heard. The Mecklenburg Quartet also gave twelve chamber concerts in the small hall of the Conservatoire.

By the time these concerts came to an end the conditions in the capital had become very serious indeed, there being scarcely any food obtainable, and the aristocracy were being quickly crushed by the Bolsheviks. Violin lessons were looked upon as a great luxury, and had I remained much longer I should most probably have found myself obliged to follow the example of the majority of the gentry and turn to manual labour in order to earn a small subsistence.

However, foreseeing horrors, I left Petrograd, and en route for England while crossing the Aland Islands on sleighs, I, with a large party of English, was unfortunately trapped by the Germans, and interned in their country for two months. But 'every dark cloud has a silver lining,' and at the last camp (Holzminden) I met a young fellow-Belgian pianist and composer, M. Goyens by name, who had already been interned there for about two years.

There were also about 4CO lady French prisoners in the camp, several of whom became very friendly with me, and begged me to arrange a concert for them together with M. Goyens. I asked the German Captain's permission (without which one could do nothing), and in an interview with him, he said: 'But I thought that the English were not musical.' However, ignoring this hit at our nation, I gained the desired permission to give a concert with the pianist, but was granted only one rehearsal. I may state here that men and women prisoners are not allowed associate in the camps.

The next step was to arrange the programme, which was not easy, as my meeting with the gentleman pianist in 